\title{
Diagnóstico higiênico-sanitário de açougues e análise microbiológica da carne bovina “in natura" (coxão mole) comercializada nos municípios da microrregião Castanhal, estado do Pará
}

\author{
Hygienic-sanitary diagnosis of butchers and microbiological analysis of "in natura" beef (coxão \\ mole) marketed in the municipalities of the Castanhal microregion, state of Pará \\ Diagnóstico higiénico-sanitario de carniceros y análisis microbiológico de la carne de vacuno "in \\ natura" (coxão mole) comercializada en los municipios de la microrregión de Castanhal, estado de \\ Pará
}

\author{
Manoel Soares Damasceno Neto \\ ORCID: https://orcid.org/0000-0002-4605-3445 \\ Universidade Federal do Pará, Brasil \\ E-mail: manoel@veterinario.med.br \\ Carina Martins de Moraes \\ ORCID: https://orcid.org/ 0000-0002-7111-8159 \\ Universidade Federal do Pará, Brasil \\ E-mail: carina_moraes@terra.com.br \\ Alessandra Fabianny Cunha de Oliveira \\ ORCID: https://orcid.org/ 0000-0001-6466-0911 \\ Universidade Federal do Pará, Brasil \\ E-mail: afabianny@hotmail.com \\ José Gatinho dos Santos Neto \\ ORCID: https://orcid.org/ 0000-0003-4244-1800 \\ Universidade Federal do Pará, Brasil \\ E-mail: jgnetoveterinario@gmail.com \\ Lorena Samara Gama Pantoja \\ ORCID: https://orcid.org/ 0000-0001-7498-2711 \\ Universidade Federal do Pará, Brasil \\ E-mail: lorena-samara@gmail.com \\ Welligton Conceição da Silva \\ ORCID: https://orcid.org/0000-0001-9287-0465 \\ Universidade Federal Rural da Amazônia, Brasil \\ E-mail: welligton.medvet@gmail.com
}

\begin{abstract}
Resumo
Objetivou-se avaliar as condições higiênico-sanitárias dos estabelecimentos comercializadores de carne bovina "in natura" da microrregião Castanhal - Pará, assim como, determinar a carga microbiana da carne comercializada nos municípios dessa microrregião. Para tal, avaliação higiênico - sanitária de 68 estabelecimentos foi realizada nos municípios de Bujarú, Castanhal, Inhangapí, Santa Izabel do Pará e Santo Antônio do Tauá, através de preenchimento de "chek list" confeccionado de acordo com a legislação brasileira. Ainda, análises de Estaphylococcus coagulase positiva, coliformes a $35^{\circ} \mathrm{C}$ e a $45^{\circ} \mathrm{C}$ e Salmonella spp. foram realizadas em 63 amostras obtidas nos estabelecimentos visitados. Os resultados obtidos, demonstraram que $88,8 \%$ dos estabelecimentos analisados apresentaram condição higiênico - sanitária insatisfatória, $6,4 \%$ dos locais foram considerados regulares e somente 4,8\% foram considerados satisfatórios. A presença de Salmonella spp. foi detectada em apenas uma amostra coletada no município de Santo Antônio do Tauá e uma amostra coletada em Inhangapi. Das amostras de carne analisadas $92 \%$ e $73 \%$ apresentaram coliformes a $35^{\circ} \mathrm{C}$ e $45^{\circ} \mathrm{C}$, superiores a $1100 \mathrm{NMP} / \mathrm{g}$, respectivamente, e as contagens de Estaphylococcus coagulase positiva variaram entre $<1,0$ x 101 e 8,4 x 102 UFC/g. Segundo a legislação brasileira, é preconizado somente pesquisa de Salmonella spp. sendo considerado impróprias para o consumo humano, mesmo quando se evidenciam altos índices de microrganismos indicadores e falhas nas condições higiênico - sanitárias dos estabelecimentos comerciais. Conclui-se que os estabelecimentos que comercializam carne bovina "in natura" da microrregião Castanhal apresentaram condição higiênico-sanitária insatisfatória, confirmada pelas altas contagens de microrganismos indicadores encontradas nas amostras estudadas.
\end{abstract}

Palavras-chave: Avaliação higiênico-sanitário; Microrregião Castanhal; Análise microbiológica; Carne. 


\begin{abstract}
Aimed to evaluate the sanitary conditions of establishments sellers of fresh beef from Castanhal microregion - Pará, as well as determine the microbial load of meat sold in the cities of the microregion. For this, hygienic - sanitary evaluation was held in 68 establishments of the cities of Bujarú, Castanhal, Inhangapí, Santa Izabel do Pará and Santo Antônio do Tauá through completion of check list made in accordance with Brazilian law. Analysis of positive Staphyloccoccus coagulase, $35^{\circ} \mathrm{C}$ and $45^{\circ} \mathrm{C}$ coliforms, and Salmonella spp. were performed in 63 samples collected in the establishments visited. The results of our study show that $88.8 \%$ of establishments had unsatisfactory hygienic condition, $6.4 \%$ of sites were considered fair and only $4.8 \%$ were considered satisfactory. The presence of Salmonella spp. was detected in only one sample collected in Santo Antônio do Tauá city and one sample collected in Inhangapi city. Meat samples analyzed $92 \%$ and $73 \%$ coliforms at $35^{\circ} \mathrm{C}$ and $45^{\circ} \mathrm{C}$, greater than $1100 \mathrm{MPN} / \mathrm{g}$, respectively, and positive Estaphylococcus coagulases counts ranged from $<1.0 \times 101$ and 8.4 x $102 \mathrm{CFU} / \mathrm{g}$. Under Brazilian law, is recommended only for Salmonella spp. being deemed unfit for human consumption, even when evidence of high levels of indicator microorganisms and failures in hygienic - sanitary commercial establishments. We conclude that establishments that sell beef "natural" condition of Castanhal microregion showed unsatisfactory sanitary conditions, confirmed by high counts of indicator microorganisms found in the samples studied.
\end{abstract}

Keywords: Hygienic - sanitary evaluation; Castanhal microregion; Microbiological evaluatin; Meat.

\title{
Resumen
}

Objetivo-se evaluar las condiciones higiénico-sanitarias de los establecimientos que comercializan carne vacuna "in natura" en la microrregión Castanhal - Pará, así como determinar la carga microbiana de la carne comercializada en los municipios de esta microrregión. Para ello, se llevó a cabo la evaluación higiénico-sanitaria de 68 establecimientos en los municipios de Bujarú, Castanhal, Inhangapí, Santa Izabel do Pará y Santo Antônio do Tauá, mediante la cumplimentación de una "lista de verificación" elaborada de acuerdo con la legislación brasileña. Además, los análisis de Staphylococcus coagulasa positivo, coliformes a $35^{\circ} \mathrm{C}$ y $45^{\circ} \mathrm{C}$, además de la investigación para Salmonella spp. se llevaron a cabo sobre 63 muestras obtenidas en los establecimientos visitados en diferentes municipios. Los resultados obtenidos mostraron que el $88,8 \%$ de los establecimientos analizados presentaban condiciones higiénicosanitarias insatisfactorias, el 6,4\% de las plazas se consideraron regulares y solo el 4,8\% satisfactorias. La presencia de Salmonella spp. se detectó en una sola muestra recolectada en el municipio de Santo Antônio do Tauá y una muestra recolectada en Inhangapi. De las muestras de carne analizadas, $92 \%$ y $73 \%$ presentaron coliformes a $35^{\circ} \mathrm{C}$ y $45^{\circ} \mathrm{C}$, superiores a $1100 \mathrm{NMP} / \mathrm{g}$, respectivamente, y los recuentos de Staphylococcus coagulasa positivos variaron entre <1.0 x 101 y 8.4 x 102 UFC / g . Según la legislación brasileña, solo las investigaciones sobre Salmonella spp. siendo considerado inadecuado para el consumo humano, aun cuando se evidencian altos niveles de microorganismos indicadores y fallas en las condiciones higiénico-sanitarias de los establecimientos comerciales. Se concluye que los establecimientos que comercializan carne bovina "in natura" de la microrregión de Castanhal presentaron un estado higiénico-sanitario insatisfactorio, confirmado por los altos conteos de microorganismos indicadores encontrados en las muestras estudiadas.

Palabras clave: Evaluación higiénico-sanitaria; Microrregión de Castanhal; Análisis microbiológico.

\section{Introdução}

A contaminação dos alimentos por microrganismos não pode ser evitada por completo, mas a aplicação de Boas Práticas de Higiene pode reduzir essa multiplicação em toda a cadeia produtiva. Durante a manipulação, os alimentos podem ser contaminados por condições precárias de higiene de manipuladores, equipamentos, utensílios, ambiente, por condições inadequadas das matérias-primas e ingredientes, ou mesmo práticas de transporte, recepção ou armazenamento incorreto dos produtos acabados (Zandonadi et al., 2007).

O conceito de qualidade de alimentos, na visão do consumidor, na grande maioria das vezes é baseado apenas na satisfação de características como sabor, aroma, aparência, embalagem, preço e disponibilidade, sendo que as condições de segurança do alimento são desconhecidas ou passam despercebidas, sendo ignorados os aspectos relacionados à influência deste alimento sobre a saúde coletiva por parte da população (Silva, 2006). No entanto, a valorização dos atributos de qualidade e de responsabilidade social vem crescendo significativamente no mercado mundial de alimentos. Percebe-se que as estratégias competitivas dos grandes grupos do setor agroalimentar procuram conquistar a confiança do consumidor no que tange à qualidade, à procedência e à sanidade dos alimentos na produção final (Vieira et al., 2010).

Segundo Rocco e Euclides Filho (2000), tanto a produção, quanto a comercialização da carne bovina, obtiveram um crescimento de aproximadamente $30 \%$ nos últimos 10 anos. No entanto, os recursos humanos necessários para a inspeção 
desse produto se mantiveram muito abaixo da necessidade. Com isso, a exigência de se produzir de forma eficiente e competitiva impõe uma produção de carne de qualidade.

De acordo com Fontoura (2006), a carne, por suas características intrínsecas, como composição química, elevada atividade de água e pH próximo da neutralidade, é um ótimo meio para a multiplicação dos microrganismos contaminantes saprófitas e ou patogênicos, colocando em risco a saúde do consumidor ou deteriorando o alimento, diminuindo dessa forma a qualidade e o período de conservação. Desta forma, a alta perecibilidade da carne e de seus derivados exige uma manipulação higiênica, para manter a contaminação microbiana em níveis aceitáveis para o consumo.

Embora seja feito um grande esforço, por parte das entidades governamentais de todo o mundo, no sentido de promover a melhoria da segurança da cadeia alimentar, a ocorrência de doenças de origem alimentar continua sendo um grave problema de saúde pública, tanto nos países desenvolvidos como nos países em desenvolvimento. Estima-se que, anualmente, 1,8 milhões de pessoas venham a óbito devido a doenças diarreicas, que, na maioria dos casos, estão ligadas a alimentos ou água contaminados (OMS, 2006).

Com base nessas informações o objetivo neste estudo foi gerar informação sobre as condições sanitárias da carne bovina "in natura" comercializada na microrregião Castanhal, estado do Pará, Brasil, através da análise microbiológica e da observação analítica e preenchimento de formulário, a respeito do emprego de procedimentos higiênico-sanitários básicos, recomendados pela legislação brasileira para manipulação e comercialização de carne bovina, em estabelecimentos legalizados e em meios de comércio informal.

\section{Metodologia}

\subsection{Local de coleta/amostragem}

Este estudo é de abordagem qualitativa, uma vez que não se considera quantificar dados estatísticos (Pereira, 2018). Para a execução do presente trabalho foram visitados 68 dos 134 estabelecimentos de comércio de carne bovina "in natura" localizados na Microrregião Castanhal, estado do Pará, segundo informações das Vigilâncias Sanitárias locais, sendo, 30 no município de Castanhal, 14 no município de Santa Izabel do Pará, 10 em Santo Antônio do Tauá, 5 em Bujarú e 9 em Inhangapí.

A microrregião de Castanhal é composta pelos municípios de Bujarú, Castanhal, Inhangapí, Santa Izabel do Pará e Santo Antônio do Tauá. O número de estabelecimentos visitados correspondeu entre 40 a $55 \%$ dos estabelecimentos cadastrados pela Vigilância Sanitária de cada município. Foram visitados os supermercados, açougues ou pontos de venda que continuamente exercem, em endereço fixo, atividade de comercialização de carne bovina para consumo, licenciados ou não. Todos os locais amostrados foram georreferenciados utilizando GPS 72H GARMIN®.

\subsection{Avaliação higiênico-sanitária dos estabelecimentos}

A avaliação das condições higiênico sanitárias e estruturais dos estabelecimentos comercializadores de carne bovina "in natura" foi realizada por no mínimo dois avaliadores, através da observação e preenchimento de ficha em formato de Chek list, confeccionada de acordo com a Resolução de Diretoria Colegiada (RDC) n 216, de 15 de setembro de 2004, da Agência Nacional de Vigilância Sanitária (ANVISA), que dispõe sobre o Regulamento Técnico de Boas Práticas para Serviços de Alimentação (Brasil, 2004). Os ítens analisados abordaram tópicos acerca da estrutura dos locais visitados (edificações, equipamentos, instrumentos e utensílios), da higiene e saúde dos manipuladores, da matéria-prima e dos insumos.

Os estabelecimentos visitados foram classificados de acordo com a percentagem de não conformidades, como insatisfatórios (estabelecimentos que obtiveram mais de $50 \%$ de não conformidade nos itens avaliados), regulares (entre $25 \% \mathrm{e}$ $49 \%$ de não conformidades) e satisfatórios (menos de $25 \%$ de não conformidades). 


\subsection{Análise microbiológica}

Análise de Staphylococcus coagulase positiva, coliformes a $35^{\circ} \mathrm{C}$ e a $45^{\circ} \mathrm{C}$, além de pesquisa de Salmonella spp. foram realizadas, de acordo com o preconizado pela Instrução Normativa n ${ }^{\circ} 62$ de 26 de agosto de 2003 do Ministério da Agricultura Pecuária e Abastecimento (MAPA), que oficializa os Métodos Analíticos Oficiais para Análises Microbiológicas para Controle de Produtos de Origem Animal e Água (Brasil, 2003).

\subsection{Coleta das amostras}

Foram coletadas 63 amostras de carne bovina "in natura" sendo, 30 amostras dos estabelecimentos do município de Castanhal, 14 do município de Santa Izabel do Pará, 10 de Santo Antônio do Tauá, 5 de Bujarú e 4 de Inhangapí. A contagem de Staphylococcus coagulase positivo foi realizada em sete das 30 amostras coletadas no município de Castanhal e em todas as amostras coletadas nos demais municípios.

Amostras de $300 \mathrm{~g}$ de coxão mole bovino resfriado foram adquiridas nos diferentes estabelecimentos comerciais visitados, com os procedimentos de manipulação e embalagem rotineiros de cada estabelecimento. A temperatura das amostras obtida foi aferida, imediatamente após a coleta, com termômetro portátil MV-360 MINIPA®, devidamente aferido e calibrado pelo fabricante. Os cortes cárneos foram acondicionados em suas embalagens plásticas originais, devidamente identificadas e transportadas em caixas isotérmicas sob refrigeração até o Laboratório de Higiene e Qualidade de Alimentos, da Universidade Federal do Pará, onde foram realizadas as análises microbiológicas.

\subsection{Preparo das amostras}

Para a realização das análises propostas, inicialmente $25 \mathrm{~g}$ de cada amostra foram devidamente homogeneizadas em $225 \mathrm{~mL}$ solução peptonada $0,1 \%$, para as análises de coliformes a $35^{\circ} \mathrm{C}$ ou $45^{\circ} \mathrm{C}$ e Staphylococcus coagulase positivo e outros $25 \mathrm{~g}$ de cada amostra foram incubadas a $37^{\circ} \mathrm{C}$, durante $16-20$ horas em $225 \mathrm{~mL}$ água peptonada tamponada, como etapa de préenriquecimento da pesquisa de Salmonella spp.

\subsection{Coliformes a $35^{\circ} \mathrm{C}$ e Termotolerantes $\left(45^{\circ} \mathrm{C}\right)$}

Para realização das referidas análises foi utilizada a técnica de Número Mais Provável (NMP). Para tal, as amostras previamente preparadas em 3 diluições (10-0, 10-1 e 10-2) preparadas em tubos de ensaio contendo caldo Lauril Sulfato de Sódio com tubos de Durhan, para realização da prova presuntiva. A partir da diluição inicial (10-1), foram inoculados volumes de $10 \mathrm{~mL}$ de cada amostra em série de 3 tubos contendo caldo Lauril Sulfato de Sódio em concentração dupla, que correspondeu à diluição $10^{\circ}$. Em seguida, inoculou-se volumes de $1 \mathrm{~mL}$ da diluição inicial (10-1) em uma segunda série de 3 tubos contendo caldo Lauril Sulfato de Sódio em concentração simples e $1 \mathrm{~mL}$ da diluição 10-2 na terceira série de 3 tubos. O material foi inoculado a $36 \pm 1^{\circ} \mathrm{C}$, por 24 a 48 horas. A suspeita de coliformes a $35^{\circ} \mathrm{C}$ foi indicada pela formação de gás nos tubos de Durhan (mínimo 1/10 do volume total) ou efervescência e as amostras possivelmente positivas foram inoculadas em caldo verde brilhante bile $2 \%$ lactose e incubados a $36 \pm 1^{\circ} \mathrm{C}$ por mais 24 a 48 horas, para realização da prova confirmativa para coliformes a $35^{\circ} \mathrm{C}$. Para a realização da prova confirmatória para coliformes termotolerantes, os tubos positivos na prova para coliformes a $35^{\circ} \mathrm{C}$ foram repicados para tubos contendo caldo Escherichia coli e incubados a $45 \pm 0,2^{\circ} \mathrm{C}$, por 24 a 48 horas. Os resultados obtidos nas provas confirmatórias foram registrados e os resultados foram obtidos através da tabela de McCrady.

\subsection{Pesquisa de Salmonella spp.}

As amostras previamente submetidas a etapa de pré-enriquecimento seletivo foram inoculadas, simultaneamente, em 
caldo Rappaport Vassiliadis e caldo Selenito cistina. Para tal, foram pipetados $0,1 \mathrm{~mL}$ das amostras préenriquecidas para tubos contendo $10 \mathrm{~mL}$ de caldo Rappaport Vassiliadis e $1 \mathrm{~mL}$ das amostras em tubos contendo $10 \mathrm{~mL}$ de caldo Selenito cistina. Os cultivos foram incubados a $41 \pm 0,5^{\circ} \mathrm{C}$, durante 24 - 30 horas.

O cultivo obtido a partir dos caldos seletivos foi repicado em duplicata em Ágar Verde Brilhante Vermelho de Fenol Lactose Sacarose (BPLS) e em Ágar Xilose Lisina Desoxicolato (XLD). As placas foram incubadas a $36 \pm 1{ }^{\circ} \mathrm{C}$, durante 18-24 horas.

A partir dos cultivos em meios sólidos seletivos foram selecionadas três colônias de acordo com as características morfo-tintoriais sugestivas de Salmonella spp. em cada um dos meios de cultura utilizados. Foram consideradas colônias características e típicas aquelas incolores ou rosadas, translúcidas a opacas sobrepostas ao meio que, com crescimento, torna-se vermelho intenso para as placas com meio BPLS e ainda colônias vermelhas ou vermelhas com centros pretos em meio XLD. As colônias selecionadas foram repicadas em meio Rugai Modificado, de acordo com as especificações do fabricante, para a realização das provas bioquímicas. Amostras positivas foram submetidas à sorologia utilizando soro polivalente somático antiSalmonella (Probac do Brasil).

\subsection{Contagem de Staphylococcus coagulase positivo}

Para realização da análise, amostras previamente preparadas foram diluídas e homogeneizadas em solução salina peptonada $0,1 \%$. Para tal, a amostra anteriormente homogeneizada foi considerada a diluição 10-1, sendo as demais diluições realizadas a partir da inoculação de $1 \mathrm{~mL}$ da diluição $10-1$ em $9 \mathrm{~mL}$ de solução salina $0,1 \%$ (diluição $10-2$ ), e da inoculação de $1 \mathrm{~mL}$ da amostra $10-2$ em $9 \mathrm{~mL}$ de solução salina $0,1 \%$ (diluição 10-3).

Posteriormente, $0,1 \mathrm{~mL}$ de cada diluição foram inoculadas em duplicata sobre a superfície de placas contendo Ágar Baird-Parker suplementado com $0,5 \%$ de Telurito de Potássio e gema de ovo a $10 \%$, e incubadas a $36^{\circ} \mathrm{C} \pm 1{ }^{\circ} \mathrm{C}$, durante $30-48$ h. Após incubação, as colônias típicas e atípicas obtidas foram contadas e os resultados registrados, sendo selecionadas apenas as placas que apresentaram crescimento de 20 a 200 colônias. Três colônias negras brilhantes com anel opaco, rodeadas por halo claro característico (colônia típica) e 3 colônias que não apresentaram estas características (colônia atípica) foram repicadas em tubos contendo $3 \mathrm{~mL}$ de caldo Brain Heart Infusion (BHI) e incubadas $36^{\circ} \mathrm{C} \pm 1^{\circ} \mathrm{C}$, durante $24 \mathrm{~h}$. Passado este período, $0,3 \mathrm{~mL}$ de cada cultivo em $\mathrm{BHI}$ foram repicados em tubos contendo $0,3 \mathrm{~mL}$ de plasma de coelho e incubados a $37^{\circ} \mathrm{C}$, durante $6 \mathrm{~h}$. Amostras que apresentaram coagulação foram confirmadas como positivas e o resultado da contagem foi estabelecido através da aplicação da seguinte fórmula, descrita no Anexo IV da Instrução Normativa 62/2003, ítem 4.7.2:

$$
\mathrm{R}=\frac{\mathrm{C} \times \mathrm{c} \times \mathrm{d}}{\mathrm{r}}
$$

Sendo:

$\mathrm{R}=$ Resultado

$\mathrm{C}=$ número de colônias contadas;

$\mathrm{c}=$ número de colônias confirmadas;

$\mathrm{r}=$ número de colônias repicadas; $\mathrm{e}$,

$\mathrm{d}=$ diluição utilizada

\subsection{Análise dos dados}

Para a análise dos dados, estes foram tabelados em planilhas do Microsoft Excel ${ }^{\circledR}$ 2017, e em seguida, apresentados em forma de gráficos e tabelas. 


\section{Resultados}

\subsection{Análise das condições higiênico-sanitárias dos estabelecimentos}

Os resultados obtidos no presente estudo demonstram que em média 93,91\% dos estabelecimentos visitados apresentaram condição higiênico - sanitária insatisfatória, demonstrada pelo alto número de não conformidades detectadas através da aplicação do Chek list. Além disso, somente 4,75\% dos locais em média, foram considerados regulares quanto a higiene das instalações e 1,33\% em média, foram considerados satisfatórios, sendo que dentre estes, incluem-se dois grandes supermercados e um açougue no centro comercial do município de Castanhal.

O município de Castanhal obteve 76,7\% de resultados insatisfatórios, sendo os casos mais graves observados no mercado central municipal, assim como nos açougues das feiras livres e bairros periféricos. Os 13,3\% dos estabelecimentos considerados regulares do ponto de vista higiênico-sanitário, foram representados pelas boutiques de carne e supermercados a varejo e atacado, localizados no centro comercial e os demais $10 \%$ foram considerados satisfatórios, representados pelas duas filiais de grandes redes de supermercados, procedentes da capital Belém. Já os municípios de Santa Isabel do Pará, Santo Antônio do Tauá, Bujarú e Inhangapí apresentaram 100\% de avaliação insatisfatória, no que diz respeito aos itens avaliados neste estudo.

Nas Tabelas 1, 2 e 3, estão demonstrados os resultados obtidos através da avaliação higiênico sanitária realizada por meio da aplicação do chek list, no município de da microrregião Castanhal, Estado do Pará. Os resultados serão discutidos nos tópicos relacionados a cada município. 
Tabela 1: Condições higiênico-sanitárias das edificações, instalações, equipamentos, instrumentos e utensílios dos estabelecimentos comercializadores de carne bovina "in natura" no município de Castanhal (CAT), Santa Izabel(SI), Santo Antônio do Tauá (SAT), Bujarú (BJ), Inhangapí (IH), do Pará e, Pará, 2012.

\begin{tabular}{|c|c|c|c|c|c|c|c|c|c|c|}
\hline \multicolumn{11}{|c|}{ DADOS APRESENTADOS EM \% } \\
\hline AVALIAÇÃO & SIM & NÃO & SIM & NÃO & SIM & NÃO & SIM & NÃO & SIM & NÃO \\
\hline & CAT & CAT & SI & SI & SAT & SAT & BJ & BJ & $\mathrm{IH}$ & $\mathrm{IH}$ \\
\hline $\begin{array}{l}\text { Acabamento } \\
\text { adequado das } \\
\text { edificacões }\end{array}$ & 26,6 & 73,4 & 14,3 & 77,8 & 0 & 100 & 0 & 100 & 0 & 100 \\
\hline $\begin{array}{l}\text { Condição Adequada } \\
\text { de equipamentos }\end{array}$ & 26,6 & 73,4 & 14,3 & 85,7 & 0 & 100 & 0 & 100 & 11,1 & 88,9 \\
\hline $\begin{array}{l}\text { Presença de } \\
\text { expositor frigorífico } \\
\text { para conservação do } \\
\text { produto }\end{array}$ & 77,7 & 23,3 & 73,3 & 26,6 & 90 & 10 & 80 & 20 & 22,2 & 77,8 \\
\hline $\begin{array}{l}\text { Utilização de } \\
\text { expositor frigorífico } \\
\text { em perfeitas } \\
\text { condições de } \\
\text { utilização e de } \\
\text { higiene }\end{array}$ & 13 & 87 & 0 & 100 & 0 & 100 & 0 & 100 & 22,2 & 77,8 \\
\hline $\begin{array}{l}\text { Iluminação } \\
\text { adequada e uso de } \\
\text { luminárias limpas, } \\
\text { protegidas e em } \\
\text { bom estado de } \\
\text { conservação }\end{array}$ & 16,6 & 83,4 & 0 & 100 & 0 & 100 & 0 & 100 & 0 & 100 \\
\hline $\begin{array}{l}\text { Ventilação } \\
\text { adequada }\end{array}$ & 16,6 & 83,4 & 0 & 100 & 0 & 100 & 0 & 100 & 22,2 & 77,8 \\
\hline $\begin{array}{l}\text { Presença de } \\
\text { lavatórios adequado }\end{array}$ & 13,3 & 86,7 & 14,3 & 77,8 & 0 & 100 & 0 & 100 & 44,4 & 56,6 \\
\hline $\begin{array}{l}\text { Presença de sabão } \\
\text { líquido antisséptico, } \\
\text { escova para mãos, } \\
\text { desinfetantes e } \\
\text { sistema higiênico } \\
\text { para secagem das } \\
\text { mãos }\end{array}$ & 13,3 & 86,7 & 0 & 100 & 0 & 100 & 0 & 100 & 22,2 & 77,8 \\
\hline $\begin{array}{l}\text { Presença de lixeiras } \\
\text { apropriadas }\end{array}$ & 3,3 & 96,7 & 0 & 100 & 0 & 100 & 0 & 100 & 0 & 100 \\
\hline $\begin{array}{l}\text { Armazenamento } \\
\text { adequado do lixo } \\
\text { para coleta }\end{array}$ & 3,3 & 96,7 & 14,3 & 77,8 & 0 & 100 & 0 & 100 & 0 & 100 \\
\hline $\begin{array}{l}\text { Condições adequada } \\
\text { de higiene das } \\
\text { instalações e } \\
\text { equipamentos }\end{array}$ & 6,6 & 93,4 & 0 & 100 & 0 & 100 & 0 & 100 & 44,4 & 55,6 \\
\hline $\begin{array}{l}\text { Presença de } \\
\text { proteção contra } \\
\text { pragas }\end{array}$ & 6,6 & 93,4 & 0 & 100 & 0 & 100 & 0 & 100 & 11,1 & 88,9 \\
\hline
\end{tabular}


Tabela 2: Avaliação da higiene e saúde dos manipuladores dos estabelecimentos comercializadores de carne bovina no município de Castanhal (CAT), Santa Izabel (SI), Santo Antônio do Tauá (SAT), Bujarú (BJ), Inhangapí (IH), do Pará e, Pará, 2012.

\begin{tabular}{|c|c|c|c|c|c|c|c|c|c|c|}
\hline \multicolumn{11}{|c|}{ DADOS APRESENTADOS EM \% } \\
\hline & SIM & NÃO & SIM & NÃO & SIM & NÃO & SIM & NÃO & SIM & NÃO \\
\hline AVALIAÇÃO & CAT & CAT & SI & SI & SAT & SAT & BJ & $\mathrm{BJ}$ & $\mathrm{IH}$ & $\mathrm{IH}$ \\
\hline $\begin{array}{l}\text { Capacitação do } \\
\text { manipulador }\end{array}$ & 13.3 & 86.7 & 0 & 100 & 0 & 100 & 0 & 100 & 0 & 100 \\
\hline Controle de saúde & 13,3 & 86,7 & 0 & 100 & 0 & 100 & 0 & 100 & 0 & 100 \\
\hline $\begin{array}{l}\text { Uso de uniforme } \\
\text { adequado }\end{array}$ & 16,6 & 83,4 & 0 & 100 & 0 & 100 & 0 & 100 & 0 & 100 \\
\hline $\begin{array}{l}\text { Condições adequadas } \\
\text { de higiene pessoal }\end{array}$ & 13,3 & 86,7 & 0 & 100 & 0 & 100 & 0 & 100 & 22,2 & 77,8 \\
\hline
\end{tabular}

Fonte: Autores (2021).

Tabela 3: Avaliação das condições higiênico-sanitárias dos estabelecimentos comercializadores de carne bovina no município de Castanhal (CAT), Santa Izabel (SI), Santo Antônio do Tauá (SAT), Bujarú (BJ), Inhangapí (IH), do Pará e, Pará, 2012.

\begin{tabular}{|c|c|c|c|c|c|c|c|c|c|c|}
\hline \multicolumn{11}{|c|}{ DADOS APRESENTADOS EM \% } \\
\hline & SIM & $\mathrm{NÃO}$ & SIM & NÃO & SIM & NÃO & SIM & NÃO & SIM & NÃO \\
\hline & CAT & CAT & SI & SI & SAT & SAT & $\mathrm{BJ}$ & $\mathrm{BJ}$ & $\mathrm{IH}$ & $\mathrm{IH}$ \\
\hline Procedência & 100 & 0,0 & 100 & 0,0 & 100 & 0,0 & 100 & 0 & 100 & 0,0 \\
\hline $\begin{array}{l}\text { Recepção e } \\
\text { armazenamento do } \\
\text { produto até o } \\
\text { momento da venda }\end{array}$ & 77,7 & 23,3 & 7,1 & 92,9 & 60 & 40 & 0 & 100 & 100 & 0,0 \\
\hline $\begin{array}{l}\text { Condição de } \\
\text { temperatura } \\
\text { adequada para } \\
\text { conservação } \\
\text { durante a venda }\end{array}$ & 13 & 87 & 7,1 & 92,9 & 10 & 90 & 0 & 100 & 33,3 & 66,7 \\
\hline
\end{tabular}

Fonte: Autores (2021).

\subsection{Município de Castanhal}

No município de Castanhal foram visitados 30 estabelecimentos, número este equivalente a $56,6 \%$ dos estabelecimentos comercializadores de carne bovina refrigerada "in natura”, segundo a Vigilância Sanitária Municipal, que possui cadastrados 53 estabelecimentos varejistas de carne bovina em toda a área do município. Nestes locais, através da avaliação higiênico - sanitária, foi possível atestar que a carne comercializada era fornecida por matadouros-frigoríficos sob inspeção Estadual e Federal, instalados no município.

Dentre os 30 locais visitados, abrangeram-se cinco pontos de venda do mercado central municipal, cinco de supermercados, dois de açougues do centro comercial e 18 de açougues em diferentes bairros periféricos. As visitas foram realizadas em $14(41,2 \%)$ dos 34 bairros da cidade e foram coletadas amostras de um a três açougues por bairro periférico. No bairro centro ocorreu um maior número de coletas.

Todos os estabelecimentos visitados em Castanhal, apresentaram algum tipo de não conformidade nos aspectos relacionados às tabelas acima. Aspectos relacionados à utilização de expositor frigorífico, presença de lixeiras com acionamento por pedal, armazenamento do lixo, condições adequadas de higiene das instalações e equipamentos, assim como proteção contra pragas foram os mais negligenciados, tendo em vista que representaram mais de $90 \%$ de não conformidades. Além disso, as condições de manutenção das edificações e equipamentos estavam adequadas em apenas $26,6 \%$ dos locais 
visitados.

Assim como acontece em Santa Izabel do Pará, a carne comercializada na cidade é fornecida por matadourosfrigoríficos do município de Castanhal e Belém. Mesmo com a presença de expositor frigorífico para conservação do produto em quatro dos cinco locais visitados, observou-se que as amostras analisadas estavam expostas ao ambiente e não atingiram a temperatura de refrigeração adequada, estando a temperatura interna dos produtos coletados entre 14,4 e $22^{\circ} \mathrm{C}$ no momento da venda do produto. No único estabelecimento que mantinha a carne em balcão frigorífico a temperatura da carne também não se encontrava adequada.

No que diz respeito a temperatura dos produtos, embora todas as amostras tenham sido adquiridas como carne resfriada, três apresentaram temperatura interna menor que $0^{\circ} \mathrm{C}$, pois estavam armazenadas diretamente em congeladores horizontais. A amostra coletada no estabelecimento que mantinha a carne em exaustor frigorífico apresentou temperatura de conservação acima de $14^{\circ} \mathrm{C}$.

No Mercado Municipal de Castanhal (Figura $1 \mathrm{~A}, \mathrm{~B}, \mathrm{C}$, e D) a matéria prima estava exposta em temperatura ambiente e sem proteção contra insetos e fumaças, além disso, os manipuladores não utilizavam vestimenta adequada para o exercício da função. Observou-se a ausência de pia para higienização de mãos e qualquer tipo de equipamento de frio.

Figura 1: Mercado central municipal, Castanhal, Pará. A: Manipulador sem uniforme, manipulando produto em contato com a parede, superfície do balcão com sujidades, ganchos e suporte oxidados, revestimento em péssimo estado de conservação, carne exposta sem refrigeração, ambiente sujo. B: Acúmulo de produtos exposto ao ambiente. C: Presença de animais (cães), ambiente aberto e com pouca iluminação. D: Manipuladores sem uniforme adequado, utilizando adorno, manipulando carne sobre o balcão com sujidades.

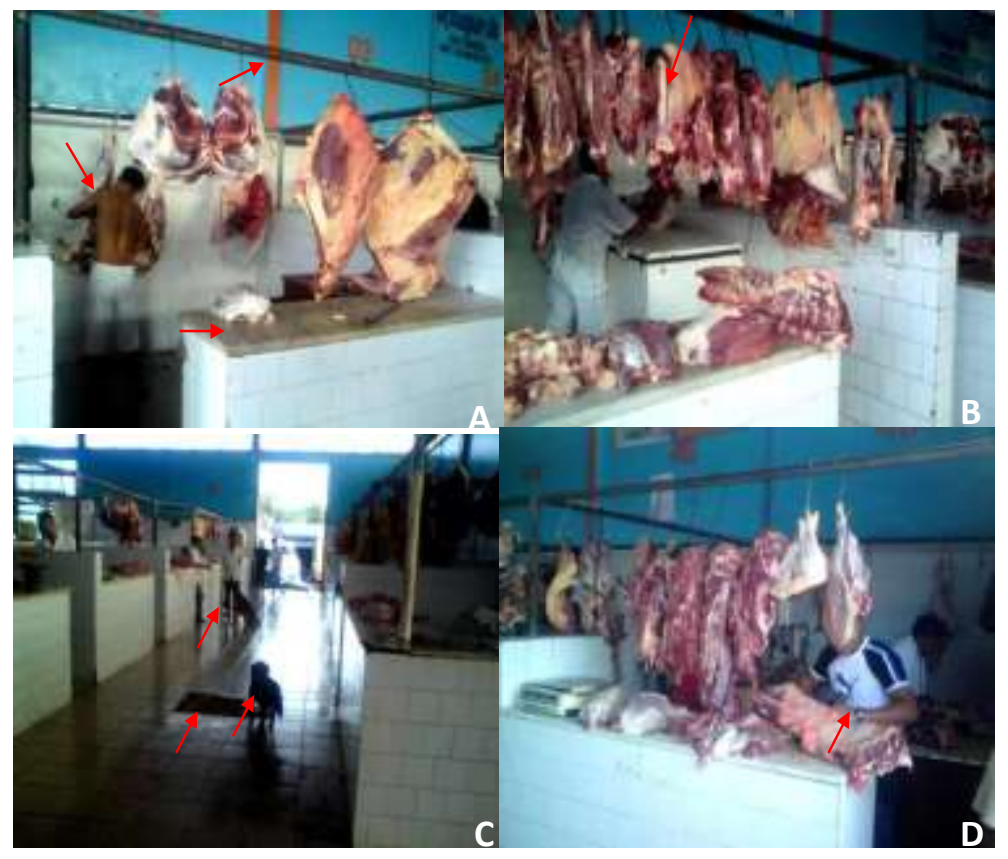

Fonte: Autores (2021).

A ventilação do local de comercialização das carnes se dava através de ventiladores e janelas com balancim, na parte superior do local. As instalações estavam em condições higiênicas precárias e foram observados revestimentos de parede e balcões em péssimo estado de conservação, além de balanças e ganchos oxidados. Observou-se exposição da carne sobre o balcão e em contato com a parede, assim como presença de cães no local, sugerindo que o controle de entrada de animais 
domésticos e pragas não são realizados.

Constatou-se que no município de Castanhal, que os proprietários dos açougues e dos box's do mercado municipal não haviam recebido qualquer tipo de treinamento sobre manipulação de alimentos, segundo informações fornecidas pelos próprios comerciantes. Em contrapartida, observou-se que nas grandes redes supermercadistas daquela cidade os manipuladores eram devidamente treinados em Boas Práticas e possuíam carteira de manipulador, o que não acontecia nos outros estabelecimentos, segundo relato dos comerciantes.

Os estabelecimentos que apresentaram exaustor frigorífico muitas vezes armazenavam em seu interior, além da carne bovina, carne de outras espécies animais assim como utilizavam vegetais (alface, cheiro verde) para melhorar a visualização do consumidor. Estas ações podem causar contaminação cruzada desses produtos.

$\mathrm{Na}$ região central do município de Castanhal (Figura 2 A e B), onde ocorre um maior fluxo de pessoas e possui, consequentemente, um maior número de estabelecimentos comerciais de carne bovina, foi possível constatar uma grande variedade de irregularidades. Alguns açougues do centro da cidade apresentaram edificações e equipamentos adequados. Porém, quando se avaliou a higiene do local e normas de Boas Práticas de Manipulação, observaram-se índices de não conformidades elevados, além de falhas operacionais. Estes açougues não realizavam qualquer controle de saúde de seus manipuladores e estes não participavam de nenhum treinamento realizado pela Vigilância Sanitária local, segundo informação dos comerciantes.

Figura 2: Açougues da região central, Castanhal, Pará. A. Acúmulo de produtos, carnes expostas a contaminação ambiental, sem refrigeração. B. Açougue apresentando equipamentos adequados, ambiente iluminado, expositor frigorífico adequado.

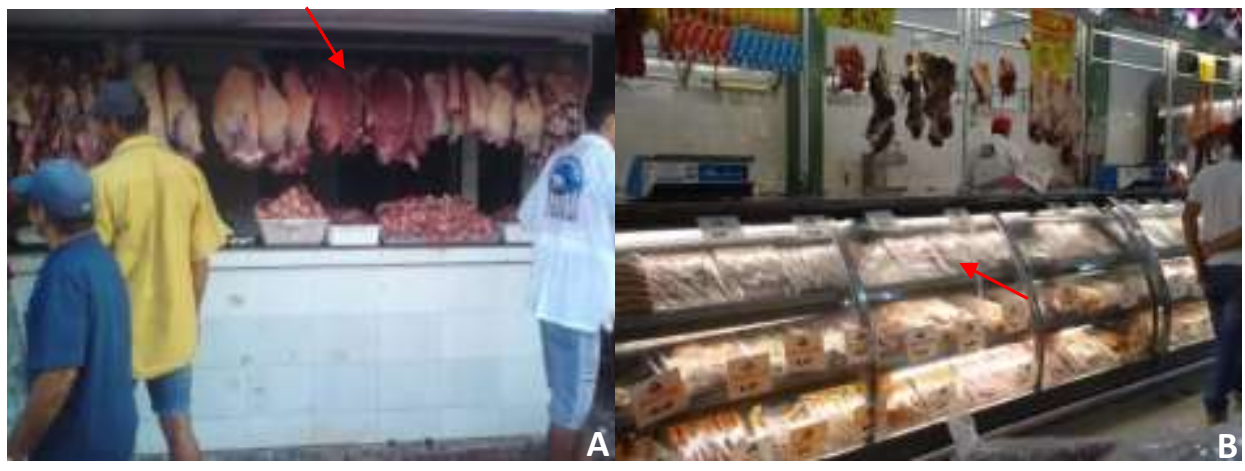

Fonte: Autores (2021).

Dessa forma, as principais alterações encontradas caracterizavam-se por uso incompleto de uniformes, favorecendo uma possível contaminação do manipulador e da carne; lixo dentro e fora dos açougues, onde, as lixeiras quando presentes, apresentavam-se sujas, sem pedal articulável e destampadas, possibilitando o aparecimento de insetos e roedores; carne exposta à contaminação ambiental (principalmente devido ao grande fluxo de veículos e pedestres no centro comercial e sujidades) e ausência de proteção contra roedores e animais, que normalmente estão presentes em feiras dos centros comerciais.

Os manipuladores do mercado central deste município não utilizavam vestimenta adequada para o exercício da função e apresentavam-se em condições precárias de higiene. Nestes estabelecimentos, a recepção da carne era realizada no balcão, onde as peças permaneciam expostas e sem refrigeração durante a comercialização. Foi possível observar no momento da avaliação presença de moscas e cães no local, provavelmente causado pelo excesso de lixo e odor fétido característico do ambiente.

Das 30 visitas realizadas, quatro (13\%) foram em açougues de grandes supermercados (Figura 3) da cidade. Nesses 
locais, as principais não conformidades encontradas estão relacionadas com a contaminação cruzada entre carne, peixe, frango, derivados cárneos e verduras. Outra não conformidade visualizada foi a não utilização adequada de uniformes por parte dos manipuladores, além do uso de adornos e maquiagem.

Figura 3: Açougue de supermercado em Castanhal, mostrando que as edificações e instalações, Balcão frigorífico, área de recepção e armazenamento de produtos são adequados, além de manipuladores utilizando uniformes, ambiente iluminado e lâmpadas com proteção (setas).

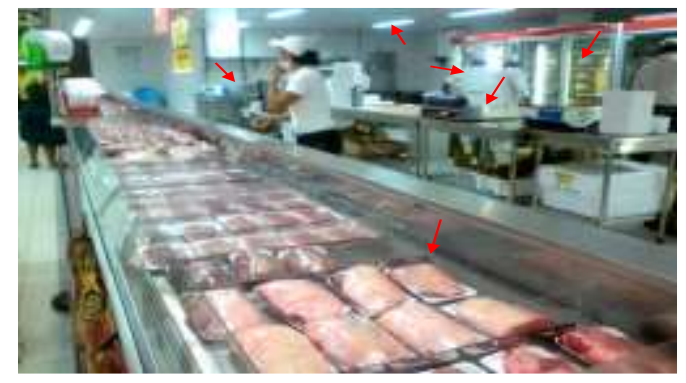

Fonte: Autores (2021).

Todos os supermercados visitados atenderam a RDC 216/2004 da ANVISA no que diz respeito às condições de manutenção das instalações, da oferta de treinamentos sobre Boas Práticas de Manipulação e higiene pessoal e de acompanhamento da saúde dos manipuladores, segundo o informado pelos comerciantes.

A região periférica da cidade possui 63,3\% dos açougues visitados (Figura 4 A e B) e as principais irregularidades encontradas, foram identificadas nos estabelecimentos desta região do município. A estrutura física dos açougues dos bairros mais afastados não possuía revestimentos nas paredes, água corrente e manutenção da temperatura adequada para a conservação do produto comercializado, além do uso inadequado de uniformes.

Figura 4: Açougues dos bairros periféricos, Castanhal, Pará. A: Exaustor frigorífico danificado, uso inadequado de uniforme, instalações e equipamentos sujos. B: Carne exposta ao ambiente, lajotas quebradas, equipamentos inadequados, ambiente sujo, manipulador sem uniforme.

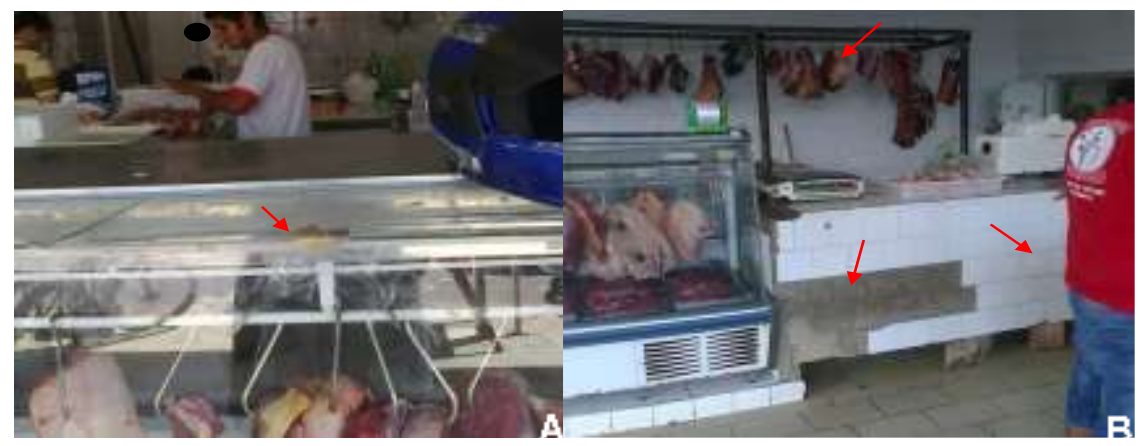

Fonte: Autores (2021).

\subsection{Município de Santa Isabel do Pará}

No que diz respeito ao município de Santa Izabel do Pará, segundo a Vigilância Sanitária Municipal, existiam 35 estabelecimentos comercializadores de carne bovina cadastrados e destes 14 (40\%) foram analisados através chek list e da análise de amostras de carne bovina. 
Em se tratando da avaliação higiênico sanitária das edificações, instalações, equipamentos, instrumentos e utensílios dos estabelecimentos avaliados neste município, os principais aspectos visualizados no chek list estão demonstrados na tabela 1.

Todos os estabelecimentos visitados nesse município, apresentavam alguma não conformidade nos aspectos relacionados na tabela acima. Aspectos relacionados a iluminação, condições de higiene e limpeza das instalações, presença de lixeiras com acionamento por pedal e proteção contra insetos e roedores foram os mais negligenciados, tendo em vista que se apresentaram $100 \%$ de não conformidades em todos os locais visitados, quanto a estes critérios. Além disso, em apenas duas $(14,3 \%)$ dos estabelecimentos havia acabamento adequado das edificações e equipamentos, presença de lavatórios e armazenamento adequado do lixo.

Em 10 (73,3\%) dos estabelecimentos havia presença de expositor frigorífico para conservação do produto, sendo que em quatro $(26,6 \%)$ a carne era exposta ao ambiente, dependurada ou dentro de congeladores horizontais juntamente com outros produtos não-cárneos, podendo ocasionar contaminação cruzada.

No mercado municipal de Santa Izabel do Pará (Figura 5) constataram-se problemas estruturais e higiênico-sanitários, onde foi observado instalações inadequadas, com abertura na parte superior, acúmulo de sujidades nas edificações, a carne estava exposta ao ambiente, além dos box's subdimensionados, lajotas danificadas, equipamentos e utensílios mal conservados e higienizados, ausência de água corrente, e condição higiênica inadequada de manipuladores que não utilizavam uniformes adequados, além da presença de cães no local.

Figura 5: Mercado Municipal, Santa Izabel do Pará. Carne exposta, ambiente aberto e com sujidades, manipulador sem uniforme adequado, acúmulo de lixo, presença de animais (cães).

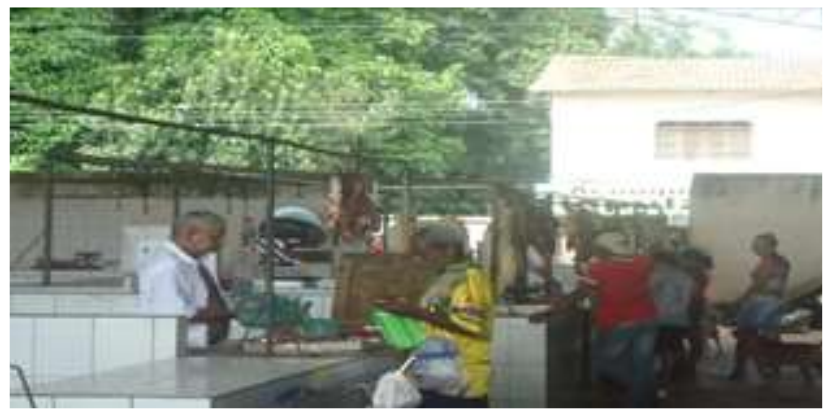

Fonte: Autores (2021).

Em nenhum local visitado foi evidenciado qualquer tipo de treinamento sobre manipulação de alimentos e os funcionários não possuíam carteira de Saúde para manipulação, segundo informação dos manipuladores. Os trabalhadores avaliados não utilizavam uniformes completos e de cores claras. $\mathrm{O}$ uso de adornos e a falta de asseio pessoal foram observados com frequência.

Segundo informação dos comerciantes e da Vigilância Sanitária, a carne comercializada naquela cidade era fornecida por matadouros-frigoríficos do município de Castanhal e Belém, pois o único frigorífico existente no município foi fechado pelos órgãos de fiscalização, por não atender as normas higiênico-sanitárias e ambientais. Porém, um estabelecimento visitado não apresentou qualquer evidência da procedência da carne comercializada.

Município de Santo Antônio do Tauá

Em se tratando do município de Santo Antônio do Tauá, a Vigilância Sanitária Municipal indicou que, no momento da realização deste estudo, existiam 25 estabelecimentos cadastrados, comercializadores de carne bovina. Destes, 10 (40\%) foram analisados através chek list e foi realizada coleta de amostras de carne bovina para realização de análises 
microbiológicas.

Os resultados obtidos a partir da avaliação higiênico-sanitária dos estabelecimentos avaliados neste município estão demonstrados na Tabela 1. Neste município, não foi observada, em nenhum estabelecimento visitado, a presença de lixeiras com pedal e os sacos contendo o lixo estavam dispostos diretamente no chão. As condições de higiene e limpeza das instalações eram inadequadas em todos os locais visitados, principalmente no mercado central, onde não havia proteção contra insetos e roedores. Os ambientes dos açougues não eram devidamente iluminados e a ventilação era precária. Neste município, a maioria dos estabelecimentos se concentrava na rodovia que atravessa a cidade e estes dividiam pequenos espaços um próximo ao outro, para comercializarem seus produtos.

Em nove (90\%) estabelecimentos havia presença de expositor frigorífico para conservação do produto, sendo que em todos eles a carne estava exposta ao ambiente, apesar da presença do equipamento de frio. A Tabela 8 demonstra os resultados obtidos durante a avaliação da higiene e saúde dos manipuladores analisados no município de Santo Antônio do Tauá.

Durante a aplicação do Chek list observou-se uma série de não conformidades operacionais e de higiene pessoal tais como uso de adornos, não utilização de uniforme, e manipulação concomitante de dinheiro e do produto, sem higienização prévia das mãos. Os funcionários não apresentavam carteira de saúde.

Segundo informação dos comerciantes e da Vigilância Sanitária, a carne comercializada na cidade é fornecida por matadouros-frigoríficos do município de Castanhal e Belém, assim como dos municípios de Bujarú e Santa Izabel do Pará.

\subsection{Município de Bujarú}

No que diz respeito ao município de Bujarú, somente 12 estabelecimentos comercializadores de carne bovina estão cadastrados junto a Vigilância Sanitária e foi realizada avaliação-higiênico sanitária em cinco estabelecimentos, o que corresponde a $41,6 \%$ do total de estabelecimentos registrados pelo serviço de fiscalização oficial do município.

Os dados referentes à avaliação higiênico sanitária dos comércios de carne bovina avaliados neste município estão descritos nas tabelas (Tabelas 1, 2 e 3). Observou-se que quatro (80\%) dos estabelecimentos amostrados, possuíam balcão frigorífico. Entretanto, todos os outros pontos do chek list foram considerados não conformes em $100 \%$ dos estabelecimentos visitados, demonstrando a precariedade deste município no que diz respeito a segurança do alimento.

Em nenhum dos locais as instalações e equipamentos estavam em conformidade, pois apresentavam paredes com revestimento inadequado, equipamentos oxidados e muitas vezes danificados. Um estabelecimento apresentava suas edificações totalmente em madeira, proporcionando acúmulo de sujidades e dificultando a limpeza. A iluminação foi deficiente em todos os pontos visitados e a ventilação era inexistente, principalmente nos pontos da feira livre.

No que diz respeito a higienização destes estabelecimentos, observou-se acúmulo de lixo, gorduras e sujidades. Nenhum dos locais analisados possuía pias e torneiras com água corrente no momento da análise. Foi observado ainda, exposição da carne em temperatura ambiente.

Em nenhum local visitado foi relatado qualquer tipo de treinamento sobre manipulação de alimentos ou higiene pessoal. Além disso, nenhum dos manipuladores apresentava carteira de manipulação no momento da visita. Os uniformes dos manipuladores, quando utilizados, estavam em condições de higiene precárias, além de estes apresentarem-se portando adornos, como anéis e relógios, assim como, barba por fazer e unhas não cortadas.

No mercado municipal (Figura 6 A e B) do município de Bujarú pode-se constatar os problemas estruturais próximo dos encontrados nos municípios de Castanhal e Santa Izabel do Pará, sendo possível observar sujidade nas instalações, box’s subdimensionados, suportes oxidados, equipamentos e utensílios danificados e mal higienizados, ausência de torneira com água corrente, e condição higiênica inadequada de manipuladores, ambiente aberto e presença de cães no local. 
Figura 6: Mercado municipal, Bujarú, Pará. A: Ambiente sujo e aberto, manipulador sem uniforme adequado, mesas de madeira, lajotas quebradas. B: Presença de cães no local.

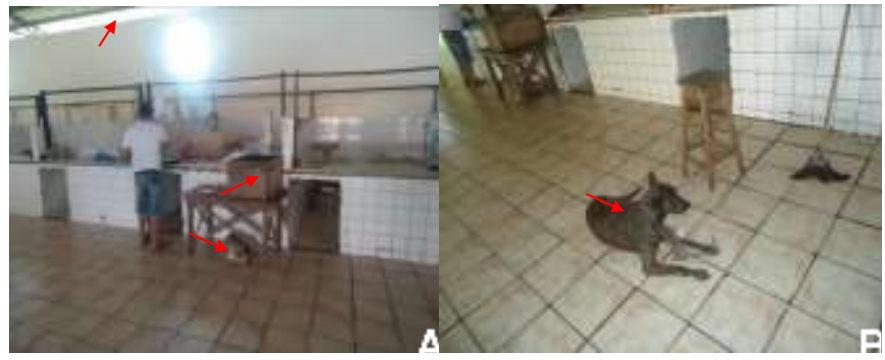

Fonte: Autores (2021).

Foi evidenciada, no mercado central, a presença de uma câmara fria comunitária, onde era armazenada a carne proveniente de todos os Box`s, no entanto, o termômetro de controle de temperatura da mesma não foi observado.

\subsection{Município de Inhangapí}

Em Inhangapí, foi realizada avaliação higiênico-sanitária em nove estabelecimentos, número este equivalente a 100\% dos estabelecimentos comercializadores de carne bovina "in natura", segundo a Vigilância Sanitária Municipal. Todos os estabelecimentos visitados são cadastrados na secretaria de Vigilância Sanitária do município sendo que, este município, é caracterizado por comercializar a carne em casas comerciais caracterizadas como minimercados, onde os mesmos mantêm a carne em congelador horizontal, juntamente com outros produtos perecíveis, até o momento da venda (Figura 7).

Figura 7: "Minimercado", local de venda de carne no município de Inhangapí, Pará. Presença de congelador horizontal para manutenção do produto.

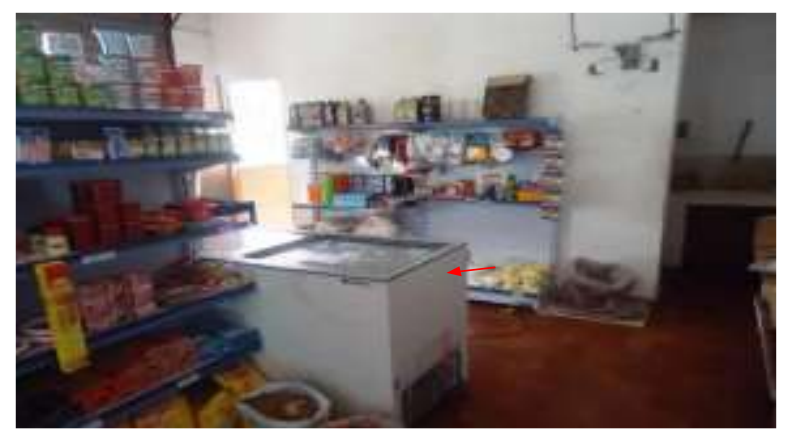

Fonte: Autores (2021).

De todos os estabelecimentos visitados, foram coletadas amostras de carne em quatro $(44,4 \%)$ para realização das análises microbiológicas previstas na metodologia deste trabalho. Uma característica deste município é que a comercialização principal é de carne com osso, não sendo observada a comercialização de cortes de alto valor comercial como picanha, filé ou contrafilé no momento da avaliação. De acordo com informações dos manipuladores, estes cortes são comercializados somente aos sábados, onde há uma maior movimentação comercial, tendo em vista ser o dia em que, grande parte dos residentes na área rural, desloca-se para à cidade para adquirir seus mantimentos.

No que diz respeito aos aspectos relacionados a edificações, iluminação, presença de lixeiras com acionamento por pedal e armazenamento do lixo, assim como, presença de proteção contra pragas, a tabela acima demonstra que estes foram os itens mais negligenciados durante a pesquisa, pois se apresentaram não conformes em todos os locais visitados. Além disso, 
em apenas duas $(22,2 \%)$ dos estabelecimentos havia presença de balcão expositor frigorífico, sendo que em sete $(77,8 \%)$ dos estabelecimentos a carne era exposta ao ambiente, dependurada ou dentro dos congeladores horizontais juntamente com outros produtos não cárneos (Figura 8), o que poderia ocasionar contaminação cruzada dos mesmos.

Durante a aplicação do Chek list foi observado que em dois $(22,2 \%)$ dos locais visitados não foi encontrado nenhum registro de que a carne comercializada seria fornecida por frigoríficos sob inspeção sanitária.

Figura 8: Armazenamento inadequado da carne, Inhangapí, Pará. Contaminação cruzada pela Presença de outros produtos com a carne, acúmulo de produtos e gelo, oxidação, Inhangapí, Pará.

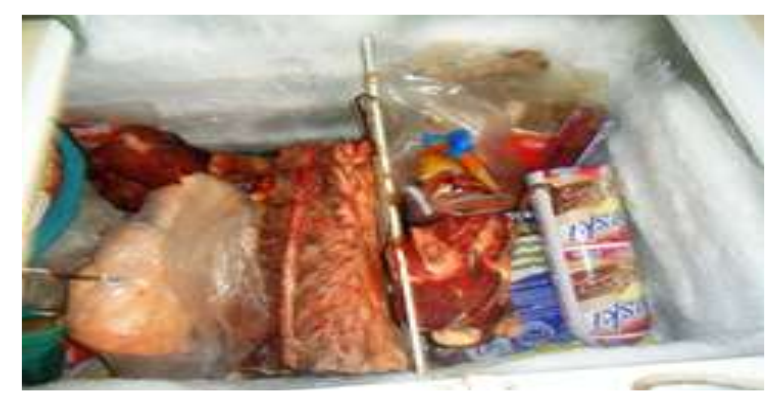

Fonte: Autores (2021).

A ventilação apresentou-se inadequada em sete $(77,8 \%)$ dos locais visitados, sendo observado ambiente com temperaturas elevadas e sem renovação do ar, levando a possibilidade de aparecimento de bolores, assim como gases, fumaça, e condensação de vapores nestes locais.

Em quatro $(44,4 \%)$ pontos de venda não havia presença de lavatórios adequados, em posição estratégica em relação ao fluxo de produção e serviço e dos cinco $(56,6 \%)$ que possuíam lavatórios, apenas duas $(22,2 \%)$ eram dotados de sabão líquido antisséptico, escova para mãos, desinfetantes, toalhas descartáveis ou outro sistema higiênico e seguro para higienização e secagem de mãos. Porém, mesmo nestes estabelecimentos, em nenhum momento durante a visita, foi verificado o manipulador higienizando as mãos.

As condições de higiene das instalações e equipamentos foram adequadas em apenas um $(11,1 \%)$ dos estabelecimentos visitados. Nos outros 8 (88,9\%) foi observado resíduos de carne no piso, acúmulo de lixo no chão e refrigerador com acúmulo de sujidades. Além disso, nenhum dos estabelecimentos apresentou qualquer tipo de controle de pragas e roedores.

Quanto à higiene e saúde dos manipuladores a tabela 14 mostra que nenhum dos funcionários observados durante as visitas utilizava uniformes de cor clara, sapatos fechados, máscaras e gorros e em sete $(77,8 \%)$ estabelecimentos, os mesmos apresentaram-se não conformes no que diz respeito ao bom asseio corporal. Além disso, em sete (77,8\%) casas comerciais, os proprietários não haviam recebido qualquer tipo de treinamento sobre manipulação de alimentos, segundo informação dos comerciantes que informaram também não possuir carteira de saúde.

Em se tratando da matéria-prima (Tabela 3), apenas um $(11,1 \%)$ estabelecimento possuía área para recepção dos produtos de tal forma que não causassem contra fluxo.

Neste município a carne é fornecida por matadouros-frigoríficos do município de Castanhal, ou, ainda, adquirida em supermercados de Castanhal e comercializadas nos minimercados da cidade. Esta situação possivelmente ocorra pela proximidade entre os dois municípios e por Inhangapí não possuir nenhum matadouro frigorífico registrado. Durante a aplicação do Chek list foi observado que em dois $(22,3 \%)$ dos locais visitados não se encontrou registro de que a carne comercializada seria fornecida por frigoríficos sob inspeção sanitária. 


\subsection{Temperatura interna das amostras de carne bovina}

Temperatura interna das amostras de carne bovina dos estabelecimentos visitados em Castanhal, 23 (77,7\%) possuíam área para recepção dos produtos e mantinham a carne em temperatura adequada até o momento de sua comercialização, uma vez que a mesma era armazenada em refrigeradores horizontais. Porém, durante as visitações pode-se constatar que em 27 (90\%) dos estabelecimentos visitados, a carne bovina não se apresentava em temperatura de refrigeração adequada no momento da venda (entre 0 e $7^{\circ} \mathrm{C}$ ) de acordo com o estabelecido por Brasil (1996), variando, no momento da coleta, entre $8,5^{\circ} \mathrm{C}$ e $29,8^{\circ} \mathrm{C}$, embora somente sete estabelecimentos visitados neste município não apresentassem exaustor frigorífico (Figura 9 A). Esta informação pode ser explicada pelo fato de que a maioria dos estabelecimentos que apresentaram amostras de carne com altas temperaturas (20 estabelecimentos) não realizavam a exposição no interior dos refrigeradores, ou possivelmente, desligavam o equipamento ou utilizavam equipamento danificado.

Figura 9: Temperatura interna das amostras de carne bovina "in natura" obtidas no município Castanhal (A), Santa Izabel(B), Santo Antônio do Tauá (C), Bujarú (D), Inhangapí (E), do Pará, 2012.
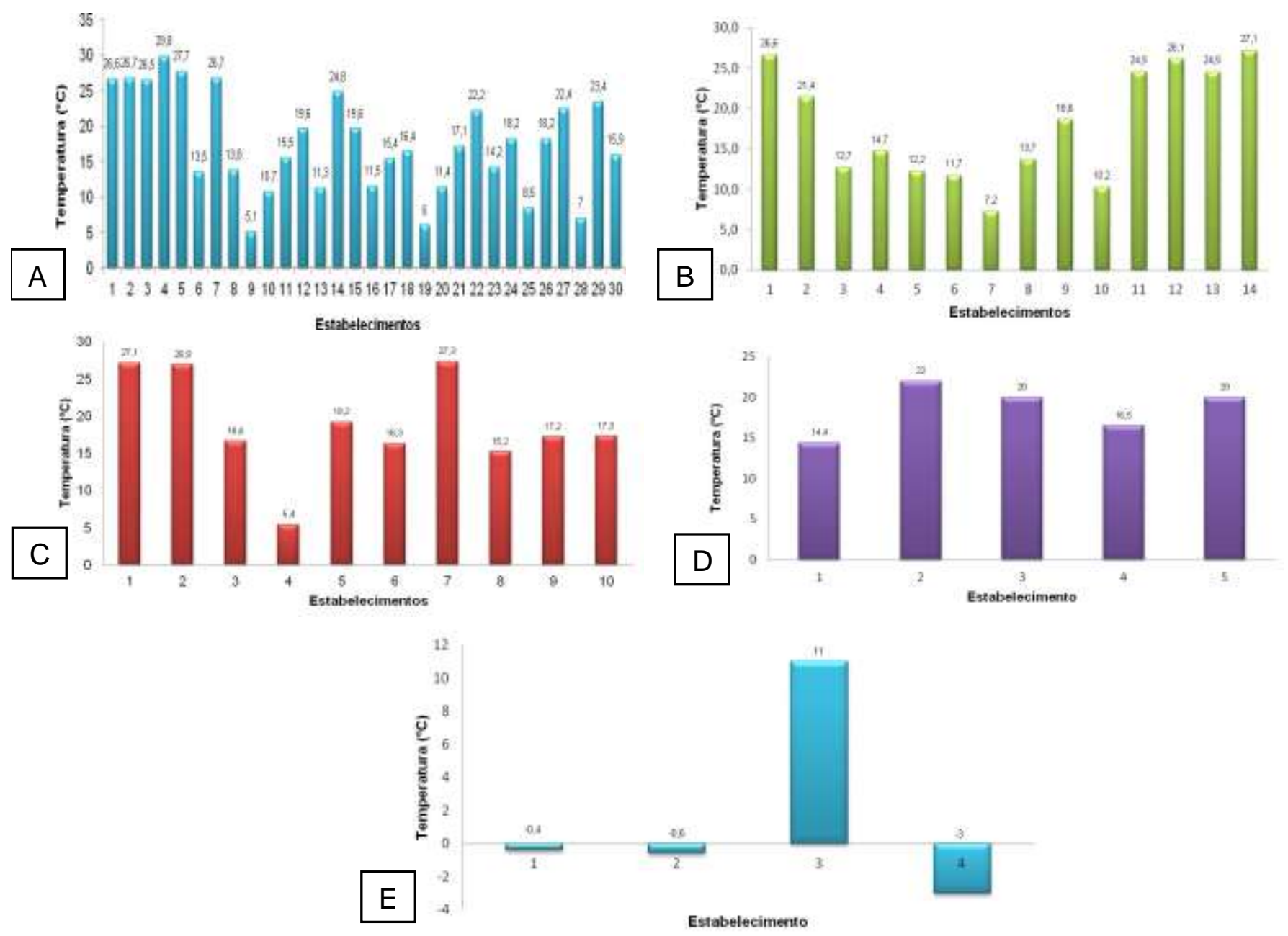

Fonte: Autores (2021).

No município de Santa Izabel, pode-se constatar que em somente um $(7,1 \%)$ estabelecimento visitado a carne bovina foi comercializada em temperatura de refrigeração adequada (entre 0 e $7^{\circ} \mathrm{C}$ ), e armazenada em congelador horizontal, juntamente com outros produtos não-cárneos. Portanto, a temperatura das carnes coletadas nos estabelecimentos estava superior àquela preconizada pela legislação vigente, pois variaram entre $7,2^{\circ} \mathrm{C}$ e $27,1^{\circ} \mathrm{C}$ no momento da coleta do produto 
(Figura 9 B).

Em Santo Antônio do Tauá, apenas um (10\%) estabelecimento visitado a carne bovina apresentava temperatura de refrigeração adequada no momento da realização deste trabalho (entre 0 e $7^{\circ} \mathrm{C}$ ), pois apesar da existência de dois exaustores frigoríficos, um estava danificado e outro apresentava-se com uma sobrecarga de produtos cárneos. A temperatura das carnes coletadas variou de 5,4 a $27,3^{\circ} \mathrm{C}$ no momento da coleta (Figura $9 \mathrm{C}$ ).

Foi possível observar que as amostras analisadas em Bujarú estavam expostas ao ambiente e não atingiram a temperatura de refrigeração adequada (Figura $9 \mathrm{D}$ ), estando a temperatura interna dos produtos coletados entre 14,4 e $22^{\circ} \mathrm{C}$ no momento da venda do produto. No único estabelecimento que mantinha a carne em balcão frigorífico a temperatura da carne também não se encontrava adequada.

No município de Inhangapí embora todas as amostras tenham sido adquiridas como carne resfriada, três apresentaram temperatura interna menor que $0^{\circ} \mathrm{C}$, pois estavam armazenadas diretamente em congeladores horizontais. A amostra coletada no estabelecimento que mantinha a carne em exaustor frigorífico apresentou temperatura de conservação acima de $14^{\circ} \mathrm{C}$ (Figura 9 E).

\subsection{Análise microbiológica}

Apenas duas (3,2\%) amostras, das 63 analisadas, apresentaram presença de Salmonella spp. sendo, uma no município de Santo Antônio do Tauá e uma em Inhangapí, o que, pela legislação brasileira, somente estas amostras estavam impróprias para o consumo. Porém, observamos que $92 \%$ das amostras analisadas apresentaram NMP superior a 1100/g para coliformes a $35^{\circ} \mathrm{C}$ e $73 \%$ para coliformes termotolerantes. Este alto índice, indica falhas de higiene dos estabelecimentos e possível presença de contaminação fecal nos produtos, propiciando risco de presença de outros microrganismos patogênicos nesses produtos.

No município de Santa Izabel do Pará, todas as análises realizadas resultaram em um alto índice de contaminação por coliformes a $35^{\circ} \mathrm{C}$ e termotolerantes $(>1100 \mathrm{NMP} / \mathrm{g}$ ), podendo estar diretamente relacionado a deficiência nas boas práticas durante a manipulação destes produtos, falhas na higienização do local e deficiências estruturais observados durante as visitas. Em se tratando de Presença de Salmonella spp., em nenhuma das amostras foi detectada tal bactéria, sendo consideradas aptas ao consumo pela legislação vigente, mesmo com os altos índices de coliformes a $35^{\circ} \mathrm{C}$ e fecais encontrados em todas as amostras analisadas.

Em Santo Antônio do Tauá todas as amostras analisadas demonstraram um alto índice de contaminação por coliformes a $35^{\circ} \mathrm{C}$ e termotolerantes (>1100 NMP/g), sendo este resultado idêntico aos encontrados nos municípios de Santa Izabel do Pará e Bujarú. No que diz respeito a detecção de Salmonella spp., uma amostra analisada (10\%) apresentou presença desta bactéria, sendo esta amostra inapropriada para o consumo (BRASIL, 2004).

No município de Bujarú, todas as análises realizadas resultaram em um alto índice de contaminação por coliformes totais e termotolerantes (>1100 NMP/g), ficando este resultado bem parecido com os dos municípios anteriores, principalmente de Santa Izabel do Pará.

Por fim, no município de Inhangapí, os resultados obtidos através das análises microbiológicas realizadas nas amostras coletadas estão expostos na tabela 20.

Em Inhangapí, igualmente as cidades de Santa Izabel do Pará, Bujarú e Santo Antônio do Tauá, as análises realizadas resultaram em um alto índice de contaminação por coliformes a $35^{\circ} \mathrm{C}$ e termotolerantes $(>1100 \mathrm{NMP} / \mathrm{g})$. No que diz respeito a detecção de Salmonella spp., assim como na cidade de Santo Antônio do Tauá, uma amostra analisada (25\%) apresentou presença desta bactéria. 


\section{Discussão}

Vários autores relatam resultados semelhantes aos encontrados neste trabalho em várias regiões do Brasil. Soto et al. (2009), ao promoverem avaliação higiênico sanitária de estabelecimentos varejistas de alimentos na cidade de Ibiúna, São Paulo, verificaram várias não conformidades sanitárias centradas principalmente na parte estrutural (localização inadequada, área com focos de insalubridade), contra fluxos e na condição higiênica inadequada dos manipuladores.

Da mesma forma, Figueredo et al. (2007), avaliando as condições sanitárias da carne bovina comercializada em feiras livres no município de Cuiabá, Mato Grosso do Sul, detectaram não conformidades semelhantes às encontradas neste trabalho nos mercados municipais e centros comerciais dos municípios visitados, pois os autores observaram presença de animais em contato com a carne e carne fresca exposta ao ar livre.

No nordeste brasileiro, Oliveira et al. (2008), ao avaliarem boxes que comercializam carnes em dois mercados públicos de Recife, Pernambuco, verificaram que 9 dos 10 itens pesquisados apresentaram não conformidade com a lista de Boas Práticas de Manipulação, onde ficou evidenciado a ausência de dispositivos que impedem a entrada de insetos em 85,7\% dos estabelecimentos, sendo constatada durante as visitas a presença de baratas em diversos boxes.

Na região norte do país, Pereira (2009), avaliando açougues do município de Tailândia, Pará, observou que nenhum dos 20 estabelecimentos visitados possuía licença de funcionamento emitida pela Vigilância Sanitária Municipal, além de os produtos à venda estarem expostos diretamente à poeira, gases provenientes do tráfego de automóveis e a contaminantes veiculados por insetos como moscas, mosquitos ou qualquer possibilidade de poluição ambiental.

Segundo dados obtidos em nosso trabalho, os estabelecimentos visitados que apresentaram melhor condição sanitária foram aqueles que funcionavam junto a redes de supermercados. Este resultado não foi observado por Valente e Passos (2004), que ao realizar avaliação higiênico - sanitária e físico - estrutural em supermercados do município de Ribeirão Preto, São Paulo, observaram deficiência em 79,3\% dos supermercados avaliados, e chamaram atenção para a importância do acompanhamento constante pela Vigilância Sanitária, com a finalidade de monitorar suas condições sanitárias destes estabelecimentos.

Sá e Moretto (2004), avaliando minimercados e supermercados em Rio do Sul, Santa Catarina, classificaram como bom 53,3\% dos estabelecimentos visitados afirmando que as maiores lojas de supermercados adequaram as menores, pelo critério de concorrência. Ainda, verificaram 100\% de adequação de balcões frigoríficos nos 15 estabelecimentos visitados naquele município. Porém, pelo menos $93 \%$ dos minimercados e supermercados visitados naquela cidade apresentou alguma irregularidade no que diz respeito as condições higiênico-sanitárias.

Outro fator que demonstrou ser um estrangulamento para a melhoria da condição higiênica dos estabelecimentos visitados no estudo em questão e, por consequência, da qualidade da carne comercializada nestes locais, foi a falta de treinamento dos manipuladores, ação está de grande importância, pois, Donkor et al. (2009), após realizarem oficinas, workshop's e treinamentos sobre segurança alimentar, indicados pela Organização Mundial da Saúde (OMS) para manipuladores de alimentos de Acra, Gana, observaram que pelo menos 67,6\% dos treinados haviam colocado em prática algum conhecimento adquirido. Porém, estes autores afirmam que embora os manipuladores de alimentos possuam informações sobre segurança e higiene do alimento, estes necessitam serem constantemente estimulados através treinamentos e orientações, para colocá-los em prática.

O armazenamento de alimentos com baixas temperaturas é a medida mais comumente usada de preservação na produção de alimentos frescos e de distribuição, e este método de conservação utilizado para o armazenamento das carcaças após o abate, cortes primários, durante o transporte de carne para os distribuidores e, finalmente, para o armazenamento da carne nos diferentes açougues. Durante todas estas fases a baixa temperatura é utilizada para reduzir a deterioração da carne através do desenvolvimento de bactérias (Ercolini et al., 2009; Ercolini et al., 2011). 
A temperatura de manutenção da carne determina por muitas vezes o desenvolvimento da carga microbiana deste produto alimentício. Os dados obtidos neste trabalho demonstraram que a carne é conservada sob temperatura inadequada em 92\% dos estabelecimentos visitados. Mantese (2004), em um trabalho que avaliou a qualidade da carne bovina no município de Porto Alegre, Rio Grande do Sul, obteve uma variação média de temperatura da carne no ponto de venda entre 6,44 a $8,9^{\circ} \mathrm{C}$, com predominância média de $7,11^{\circ} \mathrm{C}$.

Já Murmann et al. (2005), avaliando a temperatura de alimentos em estabelecimentos comerciais na cidade de Santa Maria, Rio Grande do Sul, observaram que $24,8 \%$ dos equipamentos de resfriamento apresentaram temperaturas médias inadequadas sendo que, em balcões refrigerados, a temperatura variou entre 4,62 a $13,6^{\circ} \mathrm{C}$, obtendo $31 \%$ de não conformidades para estes equipamentos, sendo os açougues responsáveis por 17,9\% das irregularidades. Ainda, Góes et al. (2004), avaliando as temperaturas de alimentos refrigerados em estabelecimentos varejistas de Salvador, Bahia, detectaram que $28,8 \%$ das carnes e derivados estudados estavam com temperatura inadequada.

O controle de pragas foi negligenciado em $97 \%$ dos estabelecimentos visitados. Estes apresentavam ambiente aberto e acúmulo de lixo em vários pontos, sendo evidenciado presenças de moscas, baratas, aranhas e formigas. Nos mercados municipais de Castanhal, Santa Izabel do Pará e Bujarú foi presenciado cães ao lado dos Box`s de venda de carne. Observou-se também vários buracos nas paredes, tetos e pisos, assim como valetas abertas, sujidades, carnes e gorduras no chão, que propiciam a presença de roedores e/ou outros vetores nestes estabelecimentos.

A análise microbiológica das amostras de carne coletada em nosso trabalho demonstrou que os produtos avaliados apresentaram contagens elevadas de coliformes a $35^{\circ} \mathrm{C}$ e $45^{\circ} \mathrm{C}$. No trabalho realizado por Xavier e Joele (2004), que pesquisou coliformes a $35^{\circ} \mathrm{C}$ e a $45^{\circ} \mathrm{C}$ em carne bovina comercializada no município de Belém, observaram que todas as amostras pesquisadas apresentaram NMP para coliformes superior a 100NMP/g. Este resultado é semelhante ao encontrado em nosso estudo, principalmente os dados observados nas cidades de Santa Izabel do Pará, Bujarú e Santo Antônio do Tauá, que obtiveram este resultado (>1100NMP/g) em 100\% das amostras analisadas.

A Resolução RDC n 12, de 2 de janeiro de 2001, do Ministério da Saúde (BRASIL, 2001) dispõe sobre o padrão microbiológico aceitável para carne bovina in natura, e determina que este alimento deve possuir ausência de Salmonella em $25 \mathrm{~g}$ de amostra. Neste trabalho detectou-se a presença deste gênero bacteriano em 3,2\% (2/63) das amostras coletadas, resultados estes bem próximos aos encontrados por Xavier e Joele, (2004), que detectaram sua presença em apenas 3,3\% (1/30) das amostras coletadas em Belém, Pará. Porém, Lundgren et al. (2009), detectaram ausência em todas as amostras avaliadas em João Pessoa, Paraíba, afirmando que este resultado não é parâmetro suficiente para assegurar a salubridade dos alimentos de origem animal, uma vez que foram encontrados outros microrganismos patogênicos como Staphylococcus coagulase positiva e padrões indicadores de contaminação fecal, observados pelo alto índice de coliformes termotolerantes.

A presença de Salmonella spp. tem sido observada em carne de várias espécies animais (Hoffmann e Romanelli, 1998; Hofer et al., 2000; Bada-Alambedji et al., 2006; Borowsky, 2007; Santos et al., 2008).

Bosilevac et al. (2009) encontraram uma prevalência de 4,2\% de Salmonella spp. em carne bovina moída, nos Estados Unidos e Kivi et al. (2007), associaram um surto de salmonelose em humanos na Holanda com o consumo de carne bovina crua em produtos pré-processados contaminada, importada de outros países europeus, gerando implicações para a política nacional e internacional daquele continente.

Os valores encontrados neste estudo demonstraram contagens de Staphylococcus coagulase positiva que variaram entre menores que 1,0 x 101, UFC/g e 8,4 x 102 UFC/g no município de Castanhal, menores que 1,0 x 101, UFC/g e 2,0 x 103 UFC/g em Santa Isabel do Pará, menores que 1,0 x 101, UFC/g e 5,3 x 102 UFC/g em Santo Antônio do Tauá e, nos municípios de Bujarú e Inhangapí todas as amostras apresentaram valores menores que 1,0 x $101 \mathrm{UFC} / \mathrm{g}$. Lundgren et al. (2009), observaram que em todas as amostras analisadas em seu trabalho foi detectada a presença de Staphylococcus coagulase 
positiva, sendo que a contagem média foi de 2,7x105 UFC/g.

Em trabalho realizado na cidade de Belém-Pará, Xavier e Joele (2004), baseados em Motta e Belmonte, (2000), consideraram produtos impróprios para consumo, amostras com resultados acima de 2,0 x $104 \mathrm{UFC} / \mathrm{g}$ e constataram que $43 \%$ das amostras pesquisadas estavam impróprias para consumo humano, pois os autores encontraram contagens de Staphylococcus aureus entre $1,0 \times 104$ e 1,0 × $107 \mathrm{UFC} / \mathrm{g}$ em carnes provenientes de feiras livres indicando dessa forma, segundo os autores, que este produto foi excessivamente manipulado. Porém, se este estudo fosse baseado pelo mesmo autor, nenhuma das amostras estaria imprópria para o consumo pelos resultados obtidos pelo mesmo. No entanto, Water et al. (2011), encontraram uma prevalência de 37\% desta bactéria em amostras de carne bovina provenientes de supermercasdos de cinco cidades do mesmo País.

\section{Conclusão}

Embora a legislação não determine padrões microbiológicos para a análise de coliformes a $35^{\circ} \mathrm{C}$ e $45^{\circ} \mathrm{C}$, conclui-se que os estabelecimentos que comercializam carne bovina "in natura" da microrregião Castanhal apresentaram condição higiênico-sanitária insatisfatória, confirmada pelas altas contagens de microrganismos indicadores encontradas nas amostras de carne procedentes dos mesmos, estudadas.

\section{Referências}

Bada-Alambedji, R., Fofana, A., Seydi, M., \& Akakpo, A. J. (2006). Antimicrobial resistance of Salmonella isolated from poultry carcasses in Dakar (Senegal). Brazilian Journal of Microbiology, 37(4).

Borowsky, L. M, Cardoso, M., \& Schimidt, V. (2007). Estimation of most probable number of Salmonella in minced pork samples. Brazilian Journal of Microbiology, 38: 544-546.

Bosilevac, J. M., Guerini, M. N., Kalchayanand, N., \& Koohmarai, M. (2009). Prevalence and Characterization of Salmonellae in Commercial Ground Beef in the United States. Applied and Environmental Microbiology, 75(7), 1892-1900.

Brasil. (1996). Ministério da Agricultura, Pecuária e Abastecimento. Gabinete do Ministro, Portaria No304 de 22 de abril de 1996 , Brasília, DF.

Brasil. (2001). Agência Nacional de Vigilância Sanitária. Resolução da Diretoria Colegiada $n^{o}$. 12 - Regulamento Técnico sobre Padrões Microbiológicos para Alimentos. Brasília, DF.

Brasil. (2003). Ministério da Agricultura, Pecuária e Abastecimento. Secretaria Nacional de Defesa Agropecuária. Laboratório Nacional de Referência Animal: Métodos Analíticos Oficiais para Controle de Produtos de Origem Animal e Água. Instrução Normativa número 62, Brasília, DF.

Brasil. (2004). Agência Nacional de Vigilância Sanitária. Resolução da Diretoria Colegiada no 216 - Regulamento Técnico de Boas Práticas para Serviços de Alimentação, Brasília, DF.

Donkor, E. S., Boniface, B., Kayang, B. B., Quaye J., \& Akyeh, M. L. (2009). Application of the WHO Keys of Safer Food to Improve Food Handling Practices of Food Vendors in a Poor Resource Community in Ghana. International Journal of Environmental Research and Public Health, 6(11): 2833-2842. Ercolini, D., Ferrocino, I., Nasi, A., Ndagijimana, M., Vernocchi, P., La Storia, A., Laghi, L., Mauriello, G., Guerzoni, M. E., Villani, F. (2011). Monitoring of microbial metabolites and bacterial diversity in beef stored under different packaging conditions. Applied and Environmental Microbiology, 77(20),73727381 .

Ercolini, D., Russo, F., Nasi, A., Ferranti, P., \& Villani, F. (2009). Mesophilic and Psychrotrophic bacteria from meat and their spoilage potential in vitro and in beef. Applied and Environmental Microbiology, 75(7), 1990-2001.

Figueredo, E. E. S., Imbelloni, M. F., Elesbão, H. S., \& Santos, A. F. (2007). Avaliação das condições higiênico-sanitárias de manipulação e comercialização de produtos de origem animal nas feiras-livres do município de Cuiabá, MT. Revista Higiene Alimentar, 21(148), 38-41.

Fontoura, C. L. (2006). Estudo microbiológico em carcaças bovinas e influência da refrigeração sobre a microbiota contaminant. Universidade Estadual Paulista. Faculdade de Ciências Agrárias e Veterinárias. Dissertação (Mestrado), São Paulo, SP.

Góes, J. A. W., Silva, A. V., Fracalossi, L. M., \& Kuwano, E. A. (2004). Condições de conservação de alimentos armazenados por refrigeração na cidade de Salvador, Bahia. Revista Higiene Alimentar, 18(125), 64-72.

Hofer, E., Zamora, M. R. N., Lopes, A. E., Moura, C. M. C., Araújo, H. L., Leite, J. D. D., Leite, M. D. D., \& Silva Filho, S. J. (2000). Sorovares de Salmonella em carne de equídeos abatidos no nordeste do Brasil. Pesquisa Veterinária Brasileira, 20(2), 80-84, 2000. 
Research, Society and Development, v. 10, n. 4, e6810413928, 2021

(CC BY 4.0) | ISSN 2525-3409 | DOI: http://dx.doi.org/10.33448/rsd-v10i4.13928

Hoffmann, F. L., \& Romanelli, P. F. (1998). Análise microbiológica da carne de jacaré do pantanal (Caiman crocodilus yacare). Ciência e Tecnologia de Alimentos, 18(3), 258-264.

Lundgren, P. U., Silva, J. A., Maciel, J. F., \& Fernandes, T. M. (2009). Profile of the hygienic-sanitary quality of bovine meat marketed at free markets and public markets of João Pessoa/PB-Brasil. Revista Alimentos Nutrição, 20(1), 113-119.

Mantese, F. D. G. (2004). Avaliação da qualidade da carne bovina comercializada no município de Porto Alegre, RS. Dissertação (Mestrado), Programa de Pós-Graduação em Zootecnia. Universidade Federal do Rio Grande do Sul, Porto Alegre, RS.

Mürmann, L., Mallmann, C. A., \& Dilkin, P. (2005). Temperaturas de armazenamento de alimentos em estabelecimentos comerciais na cidade de Santa Maria, RS. Acta Scientiae Veterinariae, 33(641), 309-313.

Oliveira, R. B. A., Rolimb, M. B. Q., Moura, A. P. B. L., \& Mota, R. A. (2008). Avaliação higiênico-sanitária dos boxes que comercializam carnes em dois mercados públicos da Cidade do Recife-PE/Brasil. Revista Medicina Veterinária, 2(4), 10-16.

OMS - Organização Mundial da Saúde. (2006). Cinco Chaves para uma alimentação mais segura: Manual. Instituto Nacional de Saúde Dr. Ricardo Jorge, Portugal.

Pereira, A. S., Shitsuka, D. M., Parreira, F. J., \& Shitsuka, R. (2018). Metodologia da pesquisa científica. UFSM. https://repositorio.ufsm.br/bitstrea $\mathrm{m} /$ handle/1/15824/Lic_Computacao_Metodologia-PesquisaCientifica.pdf?sequence $=1$

Pereira, J. B. (2009). Avaliação das boas práticas em açougues no mercado municipal de Tailândia-PA. Universidade Castelo Branco. Instituto de PósGraduação em Medicina Veterinária. Higiene e Inspeção de Produtos de Origem Animal. Belém.

Rocco, V., \& Euclides Filho, K. (2000). Qualidade da carne. Embrapa Gado de Corte, 36.

Sá, E. M. F., \& Moretto, E. (2004). Inspeção sanitária em minimercados e supermercados de Rio do Sul, SC. Revista Higiene Alimentar, 18(125), 36-40.

Santos, T. M., Martins, R. T., Santos, W. L. M., \& Martins, N. E. (2008). Inspeção Visual e avaliações bacteriológica e físico-Química da carne de piramutaba (Brachyplatistoma vaillanti) congelada. Arquivo Brasileiro Medicina Veterinária Zootecnia. 60(6), 1538-1545.

Silva, L. F. (2006). Procedimento Operacional Padronizado de Higienização como Requisitos para Segurança Alimentar em Unidades de Alimentação. Santa Maria-RS. Disponível em: <http://jararaca.ufsm.br/websites/ppgcta/download/Lazaro.pdf〉. Acesso em 20 mar 2010.

Soto, F. R. M., Cazzola, C. P. B., Oliveira, E., Sakaguti, E. H., Bernardi, F., Lúcio, D., Yamashita, N., Camargo, S. R., \& Balian, S. C. (2009). Aplicação experimental de um modelo de conduta de inspeção sanitária no comércio varejista de alimentos. Revista Ciência Tecnologia de Alimentos, 29(2), 371-374.

Valente, D., \& Passos, A. D. C. (2004). Avaliação higiênico-sanitária e físicoestrutural dos supermercados de uma cidade do sudeste do Brasil. Revista Brasileira de Epidemiologia, 7(1).

Vieira, A. C. P., Buainan, A. M., \& Spers, E. E. (2010). A segurança do alimento e a necessidade da informação aos consumidores. Cadernos de Direito, 10(19), 21-37.

Xavier, V. G., \& Joele, M. R. S. P. (2004). Avaliação das condições higiênicosanitárias da carne bovina in natura comercializada na cidade de Belém, PA. Revista Higiene Alimentar, 18(125), 64-72.

Zandonadi, R. P., Botelho, R. B. A., Sávio, K. E. O., \& Akutsu, R. C. (2007). Atitudes de risco do consumidor em restaurantes de auto-serviço. Revista de Nutrição, 20(1):19-26. 